\title{
Role of the Mast Cell in the Pulmonary
}

\section{Pressor Response to Hypoxia}

\author{
Francois HaAs and Edward H. Bergofsky \\ From the Departments of Physiology and of Rehabilitation Medicine, School of \\ Medicine, New York University, New York 10016
}

A B T R A T This study investigated the role of the mast cell in the pulmonary arterial pressor response to hypoxia. We found that pulmonary arteries $50-500 \mu$ in diameter have a predictable distribution of perivascular mast cells; that such pulmonary mast cells are degranulated in vivo during alveolar hypoxia; that hypoxia releases histamine from mast cells isolated from the peritoneal cavity without apparent injury to the cells; and that histamine is released from the lung of intact guinea pigs during alveolar hypoxia, with the rise in pulmonary vascular resistance during this period proportional to the amount of histamine released. These data point to the perivascular pulmonary mast cell in the rat and guinea pig as an important structure in the mediation of the pulmonary pressor response to hypoxia, even though the responsible humoral vasoconstrictor released from such a cell may not be histamine, or histamine alone.

\section{INTRODUCTION}

The long-standing search for the mechanism whereby hypoxia elicits pulmonary vasoconstriction has recently focused on local events at the site of the small pulmonary resistance vessel and its smooth muscle cell (1). Some of the mechanisms put forth have included: (a) depolarization of the muscle membrane (2), and (b) release of active humoral agents from surrounding tissue (3). With respect to the latter, many agents, such as catecholamines, serotonin, prostaglandins, and, in particular, histamine, have been considered (4). Recent evidence has shown that depletion of histamine, or the use of antihistamines, will diminish or abolish the pulmonary response to hypoxia $(5,6)$. The drawback to these studies, however, is that the antagonists or depleters used may be nonspecific blockers of pulmonary vasoconstriction or may even be vasodilators.

Received for publication 17 March 1972 and in revised form 23 August 1972.
The present study tests the hypothesis of locally released humoral agents through an appraisal of the role of the most obvious source of such agents, i.e., the mast cell (7). This form of investigation avoids the use of nonspecific pharmacological agents which modify the response to hypoxia and examines a different step in what may be a sequence of events leading to pulmonary vasoconstriction. The techniques involved: (a) a histological study of the distribution of mast cells around pulmonary blood vessels and the effect of hypoxia on the degree of degranulation; $(b)$ the direct measurement of humoral release from mast cells harvested from the peritoneal cavity; and $(c)$ an appraisal of the effect of hypoxia on the release of isotopically labeled histamine from the lungs of intact animals.

\section{METHODS}

Distribution of pulmonary mast cells and effect of hypoxia on degranulation. A double blind counting technique was used to determine the arrangement and degree of degranulation of pulmonary perivascular mast cells in rats made hypoxic by breathing an artificial gas mixture.

In each experiment two Wistar rats were used, each in a separate isolation cage ventilated from a tank of air. After $30 \mathrm{~min}$ the ventilating mixture of one cage was switched to an average of $12.5 \% \mathrm{O}_{2}$, balance $\mathrm{N}_{2}$, with flow and noise levels remaining constant. Although the onset of the pressor response to acute alveolar hypoxia is fairly rapid, the use of such moderate degrees of hypoxia suggested the use of a longer period of exposure (60-90 $\mathrm{min}$ ) to assure histologically visible degranulation of mast cells. Arterial blood samples at this time by cardiac puncture revealed, in the animals breathing air, a $\mathrm{pH}$ of 7.33-7.42, $\mathrm{P}_{\mathrm{CO}_{2}}$ of $32-40 \mathrm{~mm}$ $\mathrm{Hg}$ and a $\mathrm{P}_{\mathrm{O}_{2}}$ of $85-95 \mathrm{~mm} \mathrm{Hg}$. In hypoxic animals, the $\mathrm{pH}$ ranged from 7.34-7.36, the $\mathrm{P}_{\mathrm{Co}_{2}}$ from 30 to 37 , and the $\mathrm{P}_{\mathrm{O}_{2}}$ from 50 to $60 \mathrm{~mm} \mathrm{Hg}$; these $\mathrm{P}_{0_{2}}$ values yielded an average arterial $\mathrm{O}_{2}$ saturation of $82 \%$, a level in our experience usually producing pulmonary vasoconstriction. The differences in $\mathrm{pH}$ and $\mathrm{Pco}_{2}$ between the groups were not significant. After the blood samples, while still in their respective atmospheres, each rat was anesthetized with ether, the chest opened, and catheters inserted into the trachea and the pulmonary artery so that $3 \%$ formalin could be flushed through before immersing the whole lung in formalin. This 

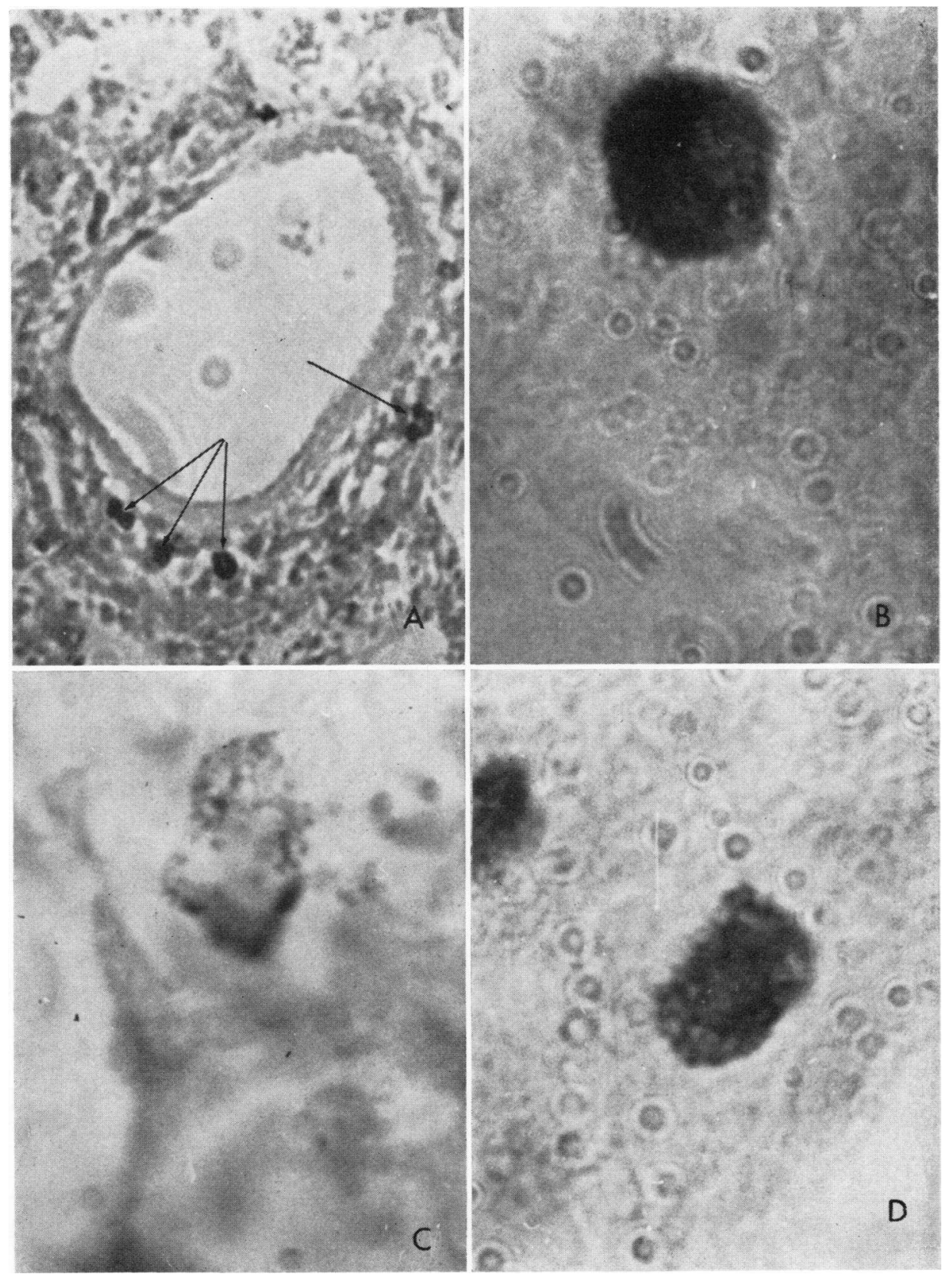

Figure 1 (A) A section through the lung of a normal Wistar rat showing the relationship between perivascular mast cells (arrows) and a blood vessel of $250 \mu$ diameter (Unna's stain, $\times 150$ ). (B) A heavily granulated perivascular mast cell (grade 1) from a normal lung $(\times 1000)$; the cytoplasm of the mast cell stains lightly; hence, the outline of the cell body is taken from the heavily staining granular aggregates. (C) A mast cell from the lung of a hypoxic rat showing advanced degranulation (grade 3$)(\times 1000)$. (D) A mast cell showing only a moderate amount of degranulation (grade 2$)(\times 1000)$.

procedure, always accomplished within $5 \mathrm{~min}$, assured rapid and uniform fixation and the removal of the cellular elements of the blood in the pulmonary vasculature.

At least four sections $(8 \mu$ thick) were made from the tissue blocks taken from each lobe of the lungs to insure a uniform survey. They were stained with "Unna's" stain, a methylene blue polychrome stain for mast-cell granules. 96 sections from the lungs of four control animals, and an equal number from four hypoxic animals, were analyzed for the number of perivascular mast cells (Fig. 1 A), the per cent of vessels surrounded by mast cells (grouped into vessels larger than $500 \mu$ and smaller than $500 \mu$ ), and the 
TABLE I

Effects of Hypoxia on Distribution and Granulation of Mast. Cells in 192 Rat Lung Microsections

\begin{tabular}{lcc}
\hline & Normoxia & Hypoxia \\
\hline 50()- $\mu$ arteries/section & & \\
With mast cells & $16 \pm 2$ & $13 \pm 2$ \\
Without mast cells & $12 \pm 3$ & $9 \pm 1$ \\
$\%$ with mast cells & $54 \pm 4$ & $59 \pm 3$ \\
Mast cells/artery with mast cells & $3.0 \pm 0.2$ & $3.2 \pm 0.1$ \\
<500- $\mu$ arteries/section & & \\
With mast cells & $37 \pm 5$ & $42 \pm 7$ \\
Without mast cells & $112 \pm 13$ & $92 \pm 13$ \\
\% with mast cells & $28 \pm 2$ & $33 \pm 4$ \\
Mast cells/artery with mast cells & $1.4 \pm 0.1$ & $1.6 \pm 0.1$ \\
& & \\
Degranulation index & & \\
Arteries $>500 \mu$ & $1.5 \pm 0.1$ & $2.6 \pm 0.1^{*}$ \\
Arteries <500 $\mu$ & $1.4 \pm 0.1$ & $2.5 \pm 0.1^{*}$ \\
& & \\
Maximal degranulation, $\%$ & & \\
Arteries $>500 \mu$ & $38 \pm 5$ & $57 \pm 7^{*}$ \\
Arteries $<500 \mu$ & $31 \pm 3$ & $53 \pm 5^{*}$ \\
\hline
\end{tabular}

* The difference in values between control and hypoxia is significant $; P<0.05$.

degree of degranulation (judged from 1 to 3 using the criteria illustrated in Figs. $1 \mathrm{~B}$ and $\mathrm{C}$ ). The investigator delivered unlabeled, but numbered, specimens to a colleague for microscopic review. This colleague tabulated findings without knowledge of each specimen's source (i.e., hypoxic or control lungs), while a third investigator collated the final results.

Effect of hypoxia on discharge of histamine from peritoneal mast cells. This approach measured the histamine released from mast cells harvested from the rat peritoneal cavity when suspended in Ringer's solution and aerated with hypoxic gas mixtures. Each experiment used six Wistar rats $(200-250 \mathrm{~g})$ which were decapitated and drained of blood in order to minimize the contamination of peritoneal fluid and the associated clotting which entraps mast cells (8). $7 \mathrm{ml}$ of heparinized Ringer's solution $(50 \mathrm{U} / \mathrm{ml})$ was injected over the intestinal surface and $5 \mathrm{ml}$ of solution was recovered, containing on the average $3 \times 10^{5}$ mast cell $/ \mathrm{ml}$. The suspensions from the six rats were pooled and divided in four $6-\mathrm{ml}$ portions. The following measurements were taken: (a) total histamine in fresh specimens; $(b)$ ratio of histamine released to that retained in mast cells; $(c)$ the same ratio after swirl-equilibration with $95 \% \mathrm{O}_{2}, 5 \% \mathrm{CO}_{2}$; and $(d)$ the same ratio after swirl-equilibration with hypoxic gas (i.e., $\left.3 \% \quad \mathrm{O}_{2}, 5 \% \mathrm{CO}_{2}, 92 \% \mathrm{~N}_{2}\right)$. $^{1}$ The imposed $\mathrm{P}_{0.2}$ of 23

${ }^{1}$ The $3 \% \quad \mathrm{O}_{2}$ imposed on the solution yielded a $\mathrm{P}_{0}$, of 23 $\mathrm{mm} \mathrm{Hg}$ at the surface of the mast cells and was therefore considered a degree of hypoxia similar to that imposed on the pulmonary arterial mast cell of the present group of intact guinea pigs and rats by the following considerations: (a) the alveolar $\mathrm{P}_{\mathrm{O}_{2}}$ to which periarterial mast cells are at least partly exposed, with inspired $\mathrm{O}_{2}$ levels of 9 and $12.5 \%$, ranges from 33 to $52 \mathrm{~mm} \mathrm{Hg}$; $(b)$ the pulmonary arterial (mixed venous) $P_{0 .}$ to which these cells are also exposed $\mathrm{mm} \mathrm{Hg}$ during hypoxia was thus considerably lower than the normal in situ ambient peritoneal $\mathrm{P}_{\mathrm{O}_{2}}$ of $52-60 \mathrm{~mm} \mathrm{Hg}$, as estimated by lymph (9). The first portion was hemolyzed with $4 \mathrm{ml}$ distilled water, the content deproteinized by addition of $0.05 \mathrm{ml}$ of $70 \% \mathrm{HClO}_{4}$ and centrifuged for 10 min at $2500 \mathrm{rpm}$, and the supernate was analyzed for histamine. The second portion was immediately centrifuged and the cellular fraction resuspended, hemolyzed, and deproteinized. The supernate was diluted by the same volume of distilled $\mathrm{H}_{2} \mathrm{O}$ and $\mathrm{HClO}_{4}$ and both fractions analyzed for histamine content. The two remaining portions were placed into swirl-equilibration flasks and handled thereafter as was the second portion.

To determine whether the histamine found during hypoxia was due to active release or to release caused by cell injury or death, the $\mathrm{O}_{2}$ consumption of the mast cell was measured under conditions identical with those outlined above. 100- 1 samples of a suspension of mast cells were taken periodically from the tonometer flask after equilibration with both high and low $\mathrm{O}_{2}$ gas mixtures. These samples were then placed in a sealed $70 \mu$ l cuvette into which was inserted a radiometer Clark microelectrode. The rate of fall of $\mathrm{P}_{0_{2}}$ was measured for $5 \mathrm{~min}$ and $\mathrm{O}_{2}$ consumption calculated. The entire experiment measuring $\mathrm{O}_{2}$ consumption at both low and high $\mathrm{P}_{\mathrm{O}}$, was performed on each of four harvests of mast cells. The suspension of cells was kept homogenous by the agitation of the swirl-equilibration flask before withdrawal of samples used to measure the rate of fall in $\mathrm{P}_{\mathrm{O}_{2}}$. The $\mathrm{O}_{2}$ electrode was calibrated by two gases (and two solutions of Ringer's solution equilibrated therewith) at 150 and 21 $\mathrm{mm} \mathrm{Hg}$. Measurements of $\mathrm{O}_{2}$ loss by electrode utilization were made with Ringer's solution equilibrated at a $\mathrm{P}_{2}$ of 150 and $21 \mathrm{~mm} \mathrm{Hg}$. This rate was subtracted from the far greater rate of loss in suspensions of $\mathrm{O}_{2}$ consuming cells. The general method of harvesting peritoneal cells produced yields that contained $75 \%$ mast cells, the remainder being mostly red blood cells with somewhat lower metabolic rates and some leukocytes; thus, the large alterations in $\mathrm{O}_{2}$ consumption in such a solution during hypoxia, to be described in Results, is due largely to the mast cells.

Histamine was determined by Shore's technique (10), condensing histamine with $o$-phthaldehyde to yield a fluorescent produce. The fluorescence (at $450 \mathrm{~m} \mu$ wavelength; excitation at $360 \mathrm{~m} \mu$ ) was measured against standard $10 \mathrm{mg} / 100 \mathrm{ml}$ histamine stock solutions diluted to give solutions of $0.1,0.05$, and $0.02 \mu \mathrm{g} / \mathrm{ml}$, and read on a Beckman ratio fluorometer (model 77205, Beckman Instruments, Inc., Fullerton, Calif.). Recovery of histamine from known samples was $80 \%$ efficient; the data have been corrected for this loss. Derivatives of histidine, of histamine, and of other vasoactive amines do not produce fluorescence at this wavelength or are discarded during extraction by $n$-butanol from an alkaline solution.

Hypoxia-induced histamine- ${ }^{1:} \mathrm{C}$ relcase by the guinca pig lung. The experiments to correlate the concentration of histamine released from the lung with the rise in pulmonary vascular resistance during alveolar hypoxia utilized a counting technique for isotopically labeled histamine rather than direct chemical analysis. This increased accuracy required would, with an arteriovenous $\mathrm{O}_{2}$ difference in the present study of $30 \%$, range from 18 to $27 \mathrm{~mm} \mathrm{Hg}$; (c) the average alveolar-pulmonary arterial $\mathrm{P}_{\mathrm{O}_{2}}$ is therefore 25 and 38 $\mathrm{mm} \mathrm{Hg}$, respectively; with further decreases in $\mathrm{P}_{0_{2}}$ due to diffusion gradients from the sources of $\mathrm{O}_{2}$ in the artery and alveolus to the mast cell, the ambient $\mathrm{P}_{\mathrm{O}_{2}}$ at this cell would be expected to be in the vicinity of $23 \mathrm{~mm} \mathrm{Hg}$.

\section{6 \\ F. Haas and E. H. Bergofsky}


that small animals be used to minimize the labeled histidine precursor. The guinea pig was chosen because it can maintain more stable levels of blood pressure and cardiac output, even after blood loss, than can the rat of equal size. In order to obtain rigorous hemodynamic studies of cardiac output and histamine release from animals having small blood volumes, two separate groups of animal were required. The first group was used to measure pulmonary arterial, left ventricular, and aortic pressures and arteriovenous $\mathrm{O}_{2}$ concentration differences $\left(\mathrm{C}_{(\mathrm{a}-\mathrm{v}) \mathrm{O}_{2}}\right)$ as an index of cardiac output, in order to assess the effect of alveolar hypoxia on pulmonary vascular resistance in the species. The second group was used to correlate the changes in pulmonary vascular resistance with the release of histamine during alveolar hypoxia.

For the first group, guinea pigs weighing 300-400 $\mathrm{g}$ were anesthetized with sodium pentobarbital $(60 \mathrm{mg} / \mathrm{kg}$ intraperitoneally), and ventilated by a positive pressure respirator through a tracheostomy. A polyethylene tube (PE 60) was threaded from the left carotid artery into either the left ventricle or the aorta. The chest was opened and a polyethylene tube ( $\mathrm{PE} \mathrm{90)} \mathrm{introduced} \mathrm{into} \mathrm{the} \mathrm{right} \mathrm{ventricle}$ and advanced into the pulmonary artery. Pressures were measured by Statham strain gauges (model P23, Statham Instruments, Inc., Oxnard, Calif.) and a Grass polygraph (Grass Instrument Co., Quincy, Mass.). After a steady state of blood pressure and arteriovenous $\mathrm{O}_{2}$ differences in room air was achieved, the animals were exposed to 8 -min periods of breathing $9 \% \mathrm{O}_{2}$, balance $\mathrm{N}_{2}$, delivered by the piston respirator. Pulmonary arterial and aortic or ventricular pressures were measured continuously except for the last minutes of this period when blood was again sampled.

The $\mathrm{C}_{(\mathrm{a}-\mathrm{v})} \mathrm{O}_{2}$ was calculated by measuring $\mathrm{P}_{\mathrm{O}_{2}}$ and $\mathrm{pH}$ by the Clark microelectrode described above. Control values for $\mathrm{P}_{\mathrm{O}_{2}}$ in $\mathrm{mm} \mathrm{Hg}$ and $\mathrm{pH}$ were $85 \pm 7$ and $7.33 \pm 0.05$, respectively. Their average Wintrobe hematocrit was normal for the guinea pig, i.e., $38.5 \pm 4 \mathrm{ml} / 100 \mathrm{ml}$ blood (11). Oxgen saturation of the blood was calculated from the $\mathrm{pH}$ and $\mathrm{P}_{\mathrm{O}_{2}}$ using the guinea pig $\mathrm{O}_{2}$ dissociation curve (12). From the $\mathrm{O}_{2}$ saturation and the hemoglobin concentration (as derived from the hematocrit) the $\mathrm{O}_{2}$ content of hemoglobin was calculated. Since the animals were kept under constant ventilation and since $\mathrm{O}_{2}$ uptake remains unchanged during moderate hypoxia $(13,14)$, an index of cardiac output was obtained directly from $\mathrm{C}_{(\mathrm{a}-\mathrm{r}) \mathrm{o}}$. To support this contention on $\mathrm{O}_{2}$ uptake in the guinea pig, a subgroup of this group was similarly anesthetized, tracheotomized, and mechanically ventilated under identical conditions in order to measure $\mathrm{O}_{2}$ uptake, $\mathrm{CO}_{2}$ production, and respiratory exchange ratio during hypoxia. The $\mathrm{O}_{2}$ uptake during normoxia averaged $2.7 \mathrm{ml} / \mathrm{min} \pm 0.2 \mathrm{sE}$ and during hypoxia, $2.6 \mathrm{ml} / \mathrm{min} \pm 0.2 \mathrm{SE}$; respiratory exchange ratios were 1.04 and 1.03 , respectively $(n=8)$.

This subgroup was also used to measure the pressurevolume characteristics of the guinea pig lung during hypoxia. Utilizing tracheal pressure during mechanical ventilation and tidal volume, pressure volume diagrams were examined under identical conditions of normoxia and hypoxia. Hypoxia caused no alteration of airway resistance and a slight increase in total thoracic compliance, i.e., from 0.52 to 0.57 $\mathrm{ml} / \mathrm{cm} \mathrm{H}_{2} \mathrm{O}(n=15)$.

The identical surgical preparation was used for the second group, which was prepared $24 \mathrm{hr}$ beforehand by injecting 5-10 ${ }_{\mu} \mathrm{Ci}$ of histidine $-{ }^{14} \mathrm{C}$ (Nuclear-Chicago Corp., Des Plaines, Ill.: universally labeled) which could be expected to be decarboxylated to histamine-L $-{ }^{14} \mathrm{C}$ (15). Arterial and
TABLE II

Effect of Hypoxia on Histamine Concentration of Rat Peritoneal Mast Cells, In Vitro

\begin{tabular}{lcc}
\hline \multicolumn{1}{c}{ Specimen } & Histamine & $\begin{array}{c}\% \text { in } \\
\text { supernate }\end{array}$ \\
\hline $\begin{array}{l}\text { Nonaerated suspensions } \\
\text { Freshly extracted }(n=9)\end{array}$ & $0.94 \pm 0.18$ & - \\
$\begin{array}{l}\text { Freshly spun }(n=8) \\
\text { cells }\end{array}$ & $0.70 \pm 0.33$ & \\
supernate \\
total
\end{tabular}

Aerated suspensions

$95 \% \mathrm{O}_{2}, 5 \% \mathrm{CO}_{2}(n=8)$

cells

$0.55 \pm 0.16$

supernate

$0.29 \pm 0.16$

total

$0.82 \pm 0.22$

$34^{*}$

$3 \% \mathrm{O}_{2}, 5 \% \mathrm{CO}_{2}(n=8)$

cells $\quad 0.38 \pm 0.15$

supernate $\quad 0.48 \pm 0.14$

total $\quad 0.87 \pm 0.27$

$53^{*}$

* The difference between the two values is significant, $P<0.05$.

venous samples $(0.25-0.40 \mathrm{ml})$ were taken during the control periods and at the end of the hypoxic periods. The cellular elements of these samples were separated by centrifuge, the supernate deproteinized, alkalinized, and extracted with $n$-butanol. Duplicate $0.4-\mathrm{ml}$ fractions were plated on gelatin-based copper planchetes and counted for $20 \mathrm{~min}$ on a Nuclear-Chicago model 1105 Spectro/Shield Automatic Low Background Planchete Sample Changer and 8703 Series Decade Scaler.

\section{RESULTS}

Effect of hypoxia on distribution and granulation of mast cells. The effect of alveolar hypoxia on the distribution and granulation of pulmonary mast cells is shown in Table I. Among vessels of more than $500 \mu$, more than $50 \%$ demonstrated clusters of perivascular mast cells. Hypoxia did not affect this distribution; in fact, the average number of mast cells in each cluster about a vessel was almost identical under control and hypoxic conditions ( 3.0 and 3.2 , respectively). With respect to vessels of less than $500 \mu$ diameter, larger numbers of vessels and cells were counted per section; however, the ratio of vessels with mast cells to total vessels was significantly smaller $(28 \%)$ than that of the larger vessels. Nonetheless, hypoxia did not change the distribution of mast cells; the number of mast cells in each cluster about a vessel was 1.4 in control animals and 1.6 in hypoxic animals. Although hypoxia did not alter the total number of visible mast cells, the degree 


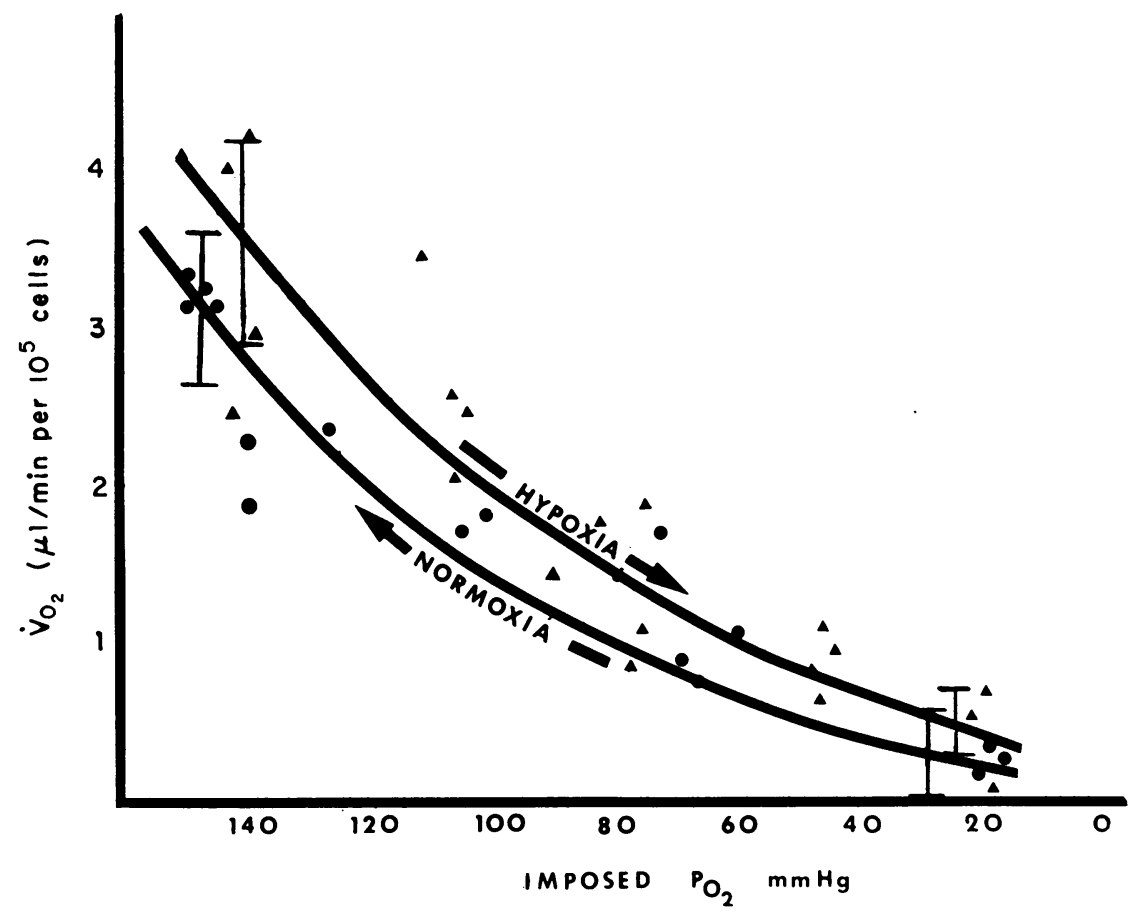

Figure 2 The relation between $\mathrm{O}_{2}$ consumption and the imposed ambient $\mathrm{P}_{\mathrm{O}_{2}}$ of rat peritoneal mast cells, in vitro. Points labeled $\boldsymbol{\Delta}$ are values for $\mathrm{O}_{2}$ consumption during continuous decreases in ambient $\mathrm{P}_{\mathrm{O}_{2}}$ toward hypoxia, whereas - are values during the subsequent increase in $\mathrm{P}_{\mathrm{O}_{2}}$ toward normal. No statistical difference is evident between the two curves, which show average values and standard deviations at $\mathrm{P}_{\mathrm{O}_{2}}$ values of 130 and $30 \mathrm{~mm} \mathrm{Hg}$.

of granulation was markedly affected. In both groups of vessels $(>500 \mu,<500 \mu)$ the degranulation index during hypoxia exceeded that during control by 73 and $70 \%$, respectively. This observation is supported (Table
I) by a significant rise in the number of maximally degranulated cells during hypoxia: for vessels of more than $500 \mu$ diameter, the percentage of maximally degranulated cells rose from $38 \%$ in the control lungs to

TABLE III

Effects of Alveolar Hypoxia on the Dynamics of the Pulnonary Circulation

\begin{tabular}{|c|c|c|c|c|c|c|}
\hline \multirow[b]{2}{*}{ Animal No. and run } & \multicolumn{2}{|c|}{$\mathrm{C}_{(\mathrm{a}-\mathbf{v}) \mathrm{O}_{2}}$} & \multicolumn{2}{|c|}{$\begin{array}{l}\text { Pulmonary arterial } \\
\text { pressure }\end{array}$} & \multicolumn{2}{|c|}{$\begin{array}{l}\text { Resistance index } \\
\left(\mathrm{P}_{\mathrm{PA}} \times \mathrm{C}_{\left.(\mathbf{a}-\mathbf{v}) \mathrm{O}_{2}\right)}\right)\end{array}$} \\
\hline & Normoxia & Hypoxia & Normoxia & Hypoxia & Normoxia & Hypoxia \\
\hline & \multicolumn{2}{|c|}{$\mathrm{ml} / 100 \mathrm{ml}$} & \multicolumn{2}{|c|}{$m m \mathrm{Hg}$} & & \\
\hline 1 & 8.6 & 6.2 & 5.0 & 8.0 & +3.0 & 49.0 \\
\hline 2 & 6.8 & 6.4 & 6.5 & 9.5 & 44.0 & 60.8 \\
\hline $3 a$ & 3.0 & 6.4 & 8.5 & 9.5 & 25.5 & 60.8 \\
\hline $3 b$ & 5.2 & 6.8 & 8.0 & 8.5 & 41.6 & 57.8 \\
\hline $3 c$ & 4.4 & 5.8 & 6.5 & 7.5 & 28.6 & 43.5 \\
\hline $4 a$ & 4.6 & 8.4 & 8.5 & 9.5 & 39.0 & 79.8 \\
\hline $4 b$ & 7.4 & 9.0 & 7.0 & 7.5 & 51.0 & 67.5 \\
\hline 5 & 4.4 & 4.2 & 9.0 & 12.0 & 39.6 & 50.4 \\
\hline $6 a$ & 5.8 & 6.8 & 8.5 & 10.0 & 49.3 & 68.0 \\
\hline $6 b$ & 8.2 & 8.2 & 6.5 & 8.5 & 53.3 & 69.7 \\
\hline $\mathrm{M} \pm \mathrm{sE}$ & $5.8 \pm 0.6$ & $6.8 \pm 0.4$ & $7.4 \pm 0.4$ & $9.1 \pm 0.4$ & $41.5 \pm 2.7$ & $60.7 \pm 3.3$ \\
\hline$P$ (paired Student's $t$ test) & \multicolumn{2}{|c|}{ NS } & \multicolumn{2}{|c|}{$<0.005$} & \multicolumn{2}{|c|}{$<0.001$} \\
\hline$P$ (nonparametric sign test) & \multicolumn{2}{|c|}{ NS } & \multicolumn{2}{|c|}{$<0.001$} & \multicolumn{2}{|c|}{$<0.001$} \\
\hline
\end{tabular}


$57 \%$ in hypoxic lungs; in the smaller vessels, the increase was from $31 \%$ during control to $53 \%$ during hypoxia.

The relatively high values of 38 and $31 \%$ for maximal degranulation in the control groups are consistent with variations in the plane of sections and the fixation by formalin, as previously observed $(16,17)$, and do not necessarily mean that considerable degranulation of cells is normally present.

Effect of hypoxia on rat peritoneal mast cells. The upper portion of Table II (nonaerated suspensions) compares the histamine content of freshly extracted and centrifuged specimens of rat peritoneal mast cells. As indicated, a freshly extracted suspension contains no more histamine $(0.94 \pm 0.18 \mu \mathrm{g} / \mathrm{ml})$ than the sum of both sedimented cell and supernate after a $10 \mathrm{~min}$ centrifugation $(1.01 \pm 0.39 \mu \mathrm{g} / \mathrm{ml})$. Within the centrifugate, the cells contain about two-thirds of the total histamine present. Aeration did not significantly reduce the total histamine in specimens swirled in tonometry flasks, nor was the distribution of histamine between cells and

TABLE IV

The Effect of Hypoxia on the Histamine-14C Content of Right and Left Ventricular Blood of Guinea Pigs

\begin{tabular}{|c|c|c|c|c|}
\hline \multirow[b]{2}{*}{$\begin{array}{c}\text { Experi- } \\
\text { ment }\end{array}$} & \multicolumn{2}{|c|}{$\begin{array}{c}\text { Normoxia } \\
\text { histamine-14 }\end{array}$} & \multicolumn{2}{|c|}{$\begin{array}{c}\text { Hypoxia } \\
\text { histamine--14 } \mathrm{C}\end{array}$} \\
\hline & $\begin{array}{c}\text { Right } \\
\text { ventricle }\end{array}$ & $\begin{array}{c}\text { Left } \\
\text { ventricle }\end{array}$ & $\begin{array}{c}\text { Right } \\
\text { ventricle }\end{array}$ & $\begin{array}{c}\text { Left } \\
\text { ventricle }\end{array}$ \\
\hline & \multicolumn{2}{|c|}{$c p m$} & \multicolumn{2}{|c|}{$c p m$} \\
\hline 1 & 60 & 75 & 65 & 95 \\
\hline 2 & 95 & 86 & 100 & 130 \\
\hline 3 & 300 & 343 & 400 & 537 \\
\hline 4 & 98 & 104 & 103 & 151 \\
\hline 5 & 50 & 54 & 55 & 71 \\
\hline 6 & 150 & 164 & 170 & 390 \\
\hline 7 & 145 & 176 & 160 & 218 \\
\hline 8 & 60 & 70 & 70 & 104 \\
\hline 9 & 75 & 69 & 75 & 78 \\
\hline 10 & 350 & 354 & 375 & 523 \\
\hline $\mathrm{M} \pm \mathrm{sE}$ & $138 \pm 31$ & $150 \pm 34$ & $157 \pm 38$ & $230 \pm 55$ \\
\hline
\end{tabular}

(1) A rise in left ventricular histamine $-{ }^{14} \mathrm{C}$ from normoxic to hypoxic periods is significant by nonparametric sign test $(P<0.001)$ and the difference of $80 \mathrm{cpm}$ between the two periods is significant by paired Student's $t$ test $(P<0.02)$. (2) The histamine-14 $\mathrm{C}$ cpm during hypoxia was significantly higher in left ventricle compared with right ventricle by nonparametric sign test $(P<0.001)$ and the difference of $73 \mathrm{cpm}$ was significant by paired Student's $t$ test $(P<0.02)$. (3) Right ventricular histamine- ${ }^{14} \mathrm{C}$ during hypoxia was significantly higher than during normoxia by nonparametric sign test $(P<0.001)$. Left ventricular histamine- ${ }^{14} \mathrm{C}$ is not significantly higher than right ventricular values during normoxia by nonparametric sign test.

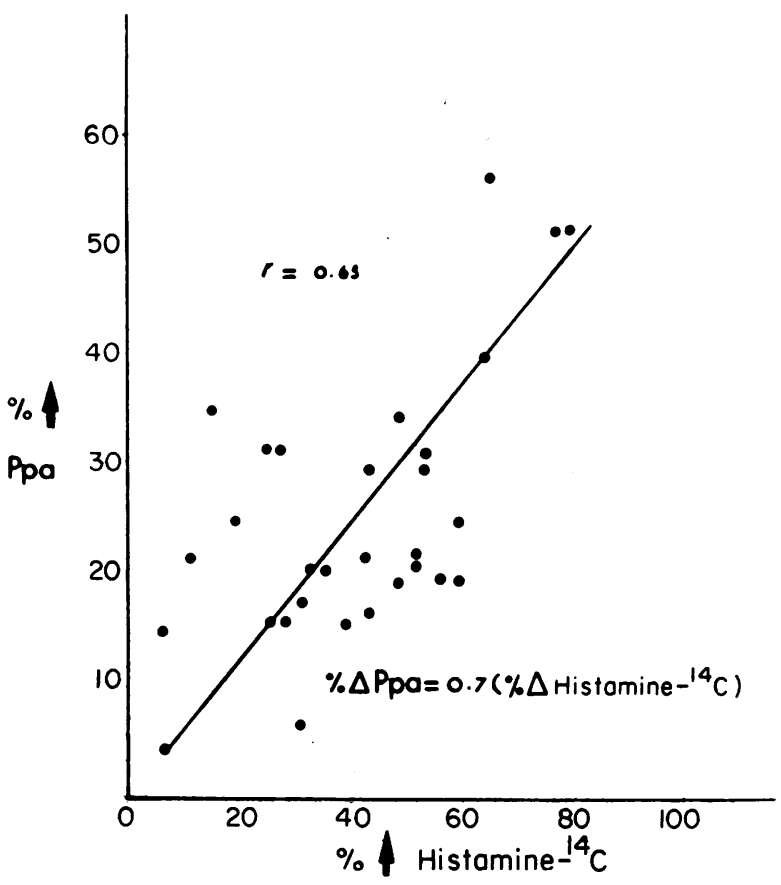

FIGURE 3 The relation between the percentile increases in pulmonary arterial pressure and the percentile increase in histamine- ${ }^{14} \mathrm{C}$ in left ventricular blood during alveolar hypoxia in the guinea pig. Each point represents data from an experimental period of steady-state alveolar hypoxia.

supernate affected. However, equilibration with hypoxic gas produced a marked and significant redistribution of histamine from cells into supernate; the histamine concentration during hypoxia averaged $53 \%$ in the supernate compared with $34 \%$ during control conditions. The $\mathrm{O}_{2}$ uptake of the isolated mast cells as a function of the various imposed $\mathrm{O}_{2}$ tensions is shown in Fig. 2. The data indicate that $\mathrm{O}_{2}$ uptake is directly related to $\mathrm{P}_{\mathrm{o}_{2}}$ (between $\mathrm{P}_{\mathrm{O}_{2}}$ of $20-140 \mathrm{~mm} \mathrm{Hg}$ ) and approaches zero as the $\mathrm{Po}_{2}$ approaches $0 \mathrm{~mm} \mathrm{Hg}$. It is thus similar to previously described behavior of mast cells (18). The viability of the cells after exposure to a low ambient $\mathrm{Po}_{2}$ is supported by the increasing $\mathrm{O}_{2}$ consumption when the same cell population is re-equilibrated with an increasing $\mathrm{P}_{\mathbf{2}}$.

Histamine release from the lung of hypoxic guinea pigs. The results of the separate hemodynamic studies determining the effects of alveolar hypoxia in the guinea pig are shown in Table III. Hypoxia caused an increase in pulmonary artery pressure in all cases while decreasing cardiac output (inverse of $\mathrm{C}(\mathrm{a}-\mathrm{v}) \mathrm{O}_{2}$ ) in 6 of the 10 experiments. These increases in mean pulmonary artery pressure (averaging $1.7 \mathrm{~mm} \mathrm{Hg}$ ) were converted to an index of pulmonary vascular resistance by utilizing the inverse of the $\mathrm{C}_{(\mathrm{a}-\mathrm{v}) \mathrm{O}_{2}}$; the average increase in this index with hypoxia was $45 \%$. Table IV com- 
pares left and right ventricular differences in histamine $-{ }^{14} \mathrm{C}$ before and during hypoxia. A wide difference in control values for labeled histamine is present because of the deliberate use of varied doses of precursor histidine $-{ }^{14} \mathrm{C}$. During room air breathing, no significant difference occurred between the average histamine content in left $(150 \mathrm{cpm})$ and right $(138 \mathrm{cpm})$ ventricular blood. During hypoxia, the histamine $-{ }^{14} \mathrm{C}$ levels in left ventricular blood emanating from the lung increased significantly over control levels ( 150 to $230 \mathrm{cpm}, P<0.02$ by paired Students $t$ test); the histamine- ${ }^{14} \mathrm{C}$ levels of the right ventricular blood draining the systemic circulation rose also during hypoxia (138 to $157 \mathrm{cpm}$. $P$ $<0.001$ by nonparametric sign test $)$.

Not shown in Table IV is the relation between histamine $-{ }^{14} \mathrm{C}$ and total ${ }^{14} \mathrm{C}$ radioactivity in the acid soluble fraction of blood (i.e., before extraction by $n$-butanol). The histamine $-{ }^{14} \mathrm{C}$ accounted for $52 \%$ of the total ${ }^{14} \mathrm{C}$ radioactivity during the control period and $82 \%$ during the hypoxic periods, indicating that the bulk of the radioactivity increase in the acid-soluble fraction of blood during hypoxia was due to histamine release.

The relationship between the release of histamine- ${ }^{14} \mathrm{C}$ from the lung and the rise in pulmonary artery pressure during hypoxia in the guinea pig is shown in Fig. 3. Each point relates the percentile increase in pulmonary arterial pressure to the percentile increase in left ventricular histamine $-{ }^{14} \mathrm{C}$ content during one or more hypoxic periods in 10 animals. The average increase in histamine ${ }^{-14} \mathrm{C}$ was $45 \pm 6 \%$ and the accompanying average percentile increase in pulmonary arterial pressure was $26.5 \pm 3 \%$. These increases were significant at $P$ levels of 0.05 and 0.02 , respectively. A linear relationship is apparent between the two variables, with a correlation coefficient of $0.65(P<0.01)$.

\section{DISCUSSION}

The present study on rats and guinea pigs has demonstrated that: (a) pulmonary vessels of $50-500 \mu$ diameter with a well-defined muscular media have a predictable distribution of mast cells within the adventitia; (b) such pulmonary mast cells are degranulated in vivo during alveolar hypoxia; $(c)$ hypoxia causes mast cells isolated from the peritoneal cavity to release histamine and possibly other humoral agents in an in vitro situation; and $(d)$ histamine is released by the lung of intact guinea pigs during alveolar hypoxia, with the rise in pulmonary arterial pressure during this period proportional to the amount of histamine released. These data deserve discussion from several points of view.

The localized clustering of mast cells around pulmonary vessels has been noted (19). The present study analyzed their distribution with respect to vascular diameter and smooth muscle thickness: in accordance with the definition of von Hayeck (20) that venous segments below a diameter of $500 \mu$ do not contain a well-defined muscle coat, the mast cells in the present study seem almost entirely distributed around pulmonary arteries. Although only an average of one-third of the arteries smaller than $500 \mu$ diameter had mast cells in any single histological section, every artery of each generation from 50 to $500 \mu$ may have adjacent mast cells in the neighboring sections. This conclusion stems from the probability that, when one-third of the arteries have mast cells in histological sections $8 \mu$ thick, the other two-thirds of the arteries will have mast cells in the next serial sections of $8 \mu$ each. Thus, for a single artery of less than $500 \mu$ diameter, 1.4 mast cells may be expected every $24 \mu$ of length. For vessels greater than $500 \mu$ diameter, since $50 \%$ of these showed mast cell clustering in any section, there would be 3.0 cells for every $16 \mu$ of vessel length. Moreover, utilizing a diameter-to-length ratio of $1: 3$ for pulmonary arteries of less than $500 \mu$ (footnote 2 ) in conjunction with the data in Table I, it can be calculated that $90,55,33,16$, and 9 mast cells will be found per vessel of $500,300,175$. 90 , and $50 \mu$ diameter.

These data permit a calculation of the amount of histamine available from mast cells during hypoxia. Assuming a value of $10^{-12} \mathrm{~g} /$ mast cell (21) and three other factors. i.e., the number of arterial segments per given generation $=2^{\mathrm{n}}$ (footnote 2 ) the estimates above of the number of mast cells per segment, and an approximate value of $50 \%$ for the amount of histamine released per cell (based on the present in vitro peritoneal mast cell results), it is possible to estimate that $10^{-5} \mathrm{~g}$ of histamine are released by arterial segments 16 through $20(60-500 \mu)$ of a whole lung during a hypoxic period. This amount of histamine has been found sufficient to increase pulmonary vascular resistance by $30 \%$ when infused into the cat (22); and such increases in pulmonary vascular resistance are similar to those spontaneously observed in the present group of animals during alveolar hypoxia.

The present data indicate that histamine is released during hypoxia from mast cells harvested from the peritoneal cavity of rats and which are therefore independent of all other neural or humoral influences. Moreover, as indicated by the oxygen consumption data, the cells survive even after the release of histamine. These data are consistent with the release of histamine and other vasoactive agents as an energy-requiring step, which can be inhibited by total lack of oxygen (23) but carried on at environmental $\mathrm{O}_{2}$ tension as low as $21 \mathrm{~mm} \mathrm{Hg}(18$, 24). Thus, from these data, the mast cell of the lung seems to fall within the general concept of a chemoreceptor cell, like that of the carotid body cells, in that: (a) it releases an active transmitter substance when the

\footnotetext{
${ }^{2}$ Domingo Gomez, personal communication.
} 
environmental $\mathrm{P}_{0_{2}}$ falls (25), and $(b)$ its drop in $\mathrm{O}_{2}$ consumption during mild hypoxia indicates a high critical $\mathrm{P}_{0_{2}}$, which would result in alterations of intracellular metabolism and consequent release of a transmitter in some proportion to the degree of hypoxia.

Although release of histamine or other substances from the lung has been noted during hypoxia previously (26), the present isotopic-labeled techniques permitted a more precise analysis of the amount released and the establishment of a relationship between the amount of histamine found in the left ventricular blood and the associated rise in pulmonary vascular resistance. The smaller increase during hypoxia of labeled histamine in the mixed venous blood, even though mast cells are widely distributed in the tissue of the guinea pig (7), may be a result either of $(a)$ rapid degradation of both pulmonary and systemically released histamine $(27)$ or $(b)$ a lower capacity of tissues other than the lung to release histamine (28).

Mast cells contain a large number of vasoactive agents (7), of which histamine is but one major constituent; in view of this, histamine was chosen as an indicator of mast cell degranulation and release of humoral agents with the reservation that it need not be the mediator, or the only mediator, of the pulmonary vasoconstrictor response to hypoxia. The role of histamine and of other possible pulmonary vasoconstrictors contained in the mast cell in the continuation of the pulmonary pressor response to hypoxia long after it has begun is uncertain from the present study. The maintenance of this response may involve an increase in the rate of synthesis of these substances by the partially degranulated mast cells so that a new steady state of increased synthesis, decreased storage pool in cellular granules, and increased release of vasoconstrictor substances is established during hypoxia.

The failure to observe bronchoconstriction as a counterpart to the vasoconstriction during alveolar hypoxia is attributable in part to the far fewer numbers of mast cells seen around the periphery of bronchi in the present histological sections. Bronchoconstriction might also be prevented if the peribronchial mast cell enjoyed higher environmental $\mathrm{O}_{2}$ tensions than the perivascular mast cell : the former has access to $\mathrm{O}_{2}$ sources composed of inspired air, alveolar air, and bronchial (systemic) arterial blood, all of which give an average $\mathrm{P}_{o_{2}}$ higher than is likely near the mast cell around the pulmonary arteries, which sees $\mathrm{O}_{2}$ sources only in the alveolus on one hand, and within the pulmonary artery (mixed venous), on the other.

\section{ACKNOWLEDGMENTS}

Supported in part by a grant from the New York Heart Association and by the Constance Getz Bresky Foundation.

\section{REFERENCES}

1. Bergofsky, E. H., F. Haas, and R. Porcelli. 1968. Determination of the sensitive vascular sites from which hypoxia and hypercapnia elicit rises in pulmonary arterial pressure. Microcirculatory society symposium on "regulation of blood vessel tone." Fed. Proc. 27: 1420.

2. Bergofsky, E. H., and S. Holtzman. 1967. A study of the mechanisms involved in the pulmonary arterial pressor response to hypoxia. Circ. Res. 20: 506.

3. Lloyd, T. C., Jr. 1968. Hypoxic pulmonary vasoconstriction: role of perivascular tissue. J. Appl. Physiol. 25: 560 .

4. Barer, G. R., and J. R. McCurrie. 1969. Pulmonary vasomotor responses in the cat; the effects and interrelationships of drugs, hypoxia and hypercapnia. $Q$. J. Exp. Physiol. 54 : 156.

5. Hauge, A. 1969. Role of histamine in hypoxic pulmonary hypertension in the rat. 1. Blockade or potentiation of endogenous amines, kinins, and ATP. Circ. Res. 22: 371.

6. Hauge, A., and N. C. Staub. 1969. Prevention of hypoxic vasoconstriction in cat lung by histamine-releasing agent 48/80. J. Appl. Physiol. 26: 693 .

7. Selye, H. 1965. The Mast Cells. Butterworths, Washington, D. C. $90,45$.

8. Glick, D., S. L. Bonting, and D. DenBoer. 1956. Use of density gradient for isolation of mast cells. Proc. Soc. Exp. Biol. Med. $92: 357$.

9. Witte, C. L., R. H. Clauss, and A. E. Dumont. 1967. Respiratory gas tensions of thoracic duct lymph: an index of gas exchange in splanchnic tissue. Ann. Surg. $166: 254$.

10. Shore, P. A., A. Burkhalter, and V. H. Cohn, Jr. 1959. A method for the fluorometric assay of histamine in tissues. J. Pharmacol. Exp. Ther. 127: 182.

11. Wintrobe, M. M., and H. B. Schumacher, Jr. 1935. Comparison of hematopoiesis in the fetus and during recovery from pernicious anemia. Together with a consideration of the relationship of fetal hematopoiesis to macrocytic anemia of pregnancy and anemia in infants. J. Clin. Invest. 14 : 837.

12. Bartels, H., and H. Harms. 1959. Sauerstoffdissoziationkurven des Blutes van Säugetieren. Pfuegers Arch. Gesamte Physiol. Menschen Tiere. 268: 334.

13. Fishman, A. P. 1961. Respiratory gases in the regulatioil of the pulmonary circulation. Physiol. Rev. 41: 214.

14. Nahas, G. G., M. B. Visscher, and F. J. Haddy. 1953. Discrepancies in cardiac output measurements by two applications of the direct Fick Principle. J. Appl. Physiol. 6 : 292.

15. Graham, P., G. Kahlson, and E. Rosengren. 1964. Histamine formation in physical exercise, anoxia and under the influence of adrenalin and related substances. $J$. Physiol. (Lond.). 172: 174.

16. Bray, R. E., and P. P. VanArsdel, Jr. 1961. In vitro histamine release from rat mast cells by chemical and physical agents. Proc. Soc. Exp. Biol. Med. 106: 255.

17. Cannizzaro, C. 1962. Le mastzellen nella mucosa laringea e tracheale mel ratto sottoposto ad azione di vapari irritanti. Boll. Mal. Orecchio. 80: 92.

18. Mongar, J. L., and B. A. V. Perera. 1965. Oxygen consumption during histamine release by antigen and compound 48/80. Immunology. 8 : 511 . 
19. Mota, I., and I. Vugman. 1956. Action of compound $48 / 80$ on the mast cells and histamine content of the guinea-pig tissues. $\mathrm{Br}$. J. Pharmacol. Chemother. 11: 304.

20. Hayeck, H. von. 1960. The Human Lung. V. E. Krahl, translator. Hafner Publishing Co., Inc., New York. 234.

21. Ellis, H. V. III, A. R. Johnson, and N. C. Moran. 1970. Selective release of histamine from rat mast cells by several drugs. J. Pharmacol. Exp. Ther. 175: 627.

22. Porcelli, R. J., and E. H. Bergofsky. 1971. Effect of $\mathrm{pH}$ on pulmonary pressor responses to humoral agents. J. Appl. Physiol. 31: 679.

23. Uvnäs, B. 1963. Mechanism of histamine release in mast cells Ann. N. Y. Acad. Sci. 103: 278.

24. Moussatché, H., and A. Prouvost-Danon. 1960. Influence de l'anaérobiose et de différentes tensions d'oxygène sur la libération d'histamine dans la réaction anaphylactique in vitro. Experientia (Basel). 16: 118.

25. Torrance, R. W. 1969. The idea of a chemoreceptor. In The Pulmonary Circulation and Interstitial Space. A. P. Fishman and H. H. Hecht, editors. University of Chicago Press, Chicago. 223.

26. Aviado, D. M., M. Samanek, and L. E. Folle. 1966. Cardiopulmonary effects of tobacco and related substances. 1. The release of histamine during inhalation of cigarette smoke and anoxemia in the heart-lung and intact dog preparation. Arch. Environ. Health. 12: 705.

27. Schayer, R. W., and J. A. D. Cooper. 1956. Metabolism of $\mathrm{C}^{14}$ histamine in man. J. Appl. Physiol. 9: 481.

28. Schayer, R. W. 1962. Evidence that induced histamine is an intrinsic regulator of the microcirculatory system. Am. J. Physiol. 202 : 66. 